Seyahat ve Otel İşletmeciliği Dergisi/

Journal of Travel and Hospitality Management

16 (3), 2019, 366-382.

Gönderim Tarihi: 22.05.2019

Kabul Tarihi: 01.08.2019

\title{
Medikal Turizm Hizmeti Veren Hastanelerde Sağlık Otelciliği Hizmetleri İle Örgütsel Ustalık İlişkisi*
}

\section{Relationship Between Healthcare Hotel Services and Organizational Ambidexterity in Hospitals Providing Medical Tourism Services}

\author{
Öğr. Gör. Dr. Seher GÜLENÇ \\ Anadolu Üniversitesi \\ İsletme Fakültesi \\ E-posta: sehergeyik@anadolu.edu.tr
}

Prof. Dr. Meryem AKOĞLAN KOZAK

Anadolu Üniversitesi

İşletme Fakültesi

E-posta: mkozak@anadolu.edu.tr

Öz

Araştırmanın amacı, sağlık otelciliği hizmetleri ile örgütsel ustalık stratejileri arasındaki ilişkilerin belirlenmesidir. Araştırmanın veri toplama sürecinde anket tekniğinden faydalanılmıştır. Ankete, Ankara'da hizmet veren devlet hastanesi (315), üniversite hastanesi (252) ve özel hastane (105) kapsamında toplam 672 çalışan katılmıştır. Toplanan anket verileri üzerinde gerçekleştirilen betimsel analizler ve ilişki testleri sonucunda, sağlık otelciliği hizmetlerinin devlet hastanesinde ve üniversite hastanesinde orta düzeyde, özel hastanede yeterli düzeyde olduğu ortaya çıkmıştır. Örgütsel ustalık durumunda ise özel hastanenin $(\bar{X}(Y S . A S)=14,17)$ devlet hastanesine $(\bar{X}$ (YS.AS) $=8,14)$ ve üniversite hastanesine $(\bar{X}$ (YS.AS) $=8,76)$ göre yararlanıcı ve araştırıCı stratejileri daha iyi birlikte kullanarak daha usta olduğu belirlenmiştir. Ayrıca, her üç hastanede sağlık otelciliği hizmetleri ile yararlanıcı ve araştırıcı stratejiler arasında pozitif ilişki olduğu saptanmıştır. Bu durum, hastanelerin sağlık otelciliği hizmetlerini yeterli düzeyde sunabilmesi için belli bir örgütsel ustalık düzeyinde bulunulması gerektiğini göstermektedir. Bu nedenle yöneticilerin sağlık otelciliği hizmetlerinin iyileştirilmesi için öncelikle örgütsel ustalığı besleyen yararlanıcı ve araştıııcı stratejilerin geliştirilmesine önem vermeleri gerekmektedir.

Anahtar Kelimeler: Sağlık Otelciliği, Örgütsel Ustalık, Ankara.

\begin{abstract}
The aim of the research is to determine the relationships between healthcare hotel services and organizational ambidexterity strategies. Data utilized in this research were collected via questionnaires. A total of 672 employees participated in the survey, from which public hospital (315), university hospital (252) and private hospital (105) all in Ankara. As a result of the descriptive analysis and correlation tests performed on the gathered information; healthcare hotel services were found to be moderate in the public and the university hospital and adequate in the private hospital. In the case of organizational ambidexterity, though, the private hospital $(\bar{X}$ $(\mathrm{YS} . \mathrm{AS})=14,17)$ was determined to be superior to the public hospital $\left(\bar{X}_{(\mathrm{YS} . \mathrm{AS})}=8,14\right)$ and the university hospital $\left(\bar{X}_{\text {(YS.AS) }}=8,76\right)$ in using exploitation and exploration strategies better. Moreover, there is a positive correlation between healthcare hotel services, and exploitation and exploration strategy in all three types of hospitals. This shows that a certain level of organizational ambidexterity is required for hospitals to provide healthcare hotel services adequately. Therefore, managers should attach importance to the development of exploitation and exploration strategies that foster organizational ambidexterity.
\end{abstract}

Key Words: Healthcare Hotel, Organizational Ambidexterity, Ankara.

*Bu çalışma Medikal Turizm Hizmeti Veren Hastanelerde Sağlık Otelciliği Hizmetleri Ile Örgütsel Ustalık ilişkisi adlı doktora tezinden üretilmiştir. 


\section{Giriş}

Günümüzde medikal turizm hizmetleri, bireylerin tedavi olma amacıyla uzun ya da kısa süreli kaldıkları hastaneler yanında, çeşitli konaklama tesislerinde de sunulmaktadır. Ancak hastanelerde esas olan tıbbî fonksiyonlar dışında, hastaya sunulan konaklama ve yiyecek hizmetlerinin tıpkı bir otel işletmesindeki yaklaşımla sunuluyor olmasıdır (Sevin, 1998: 26). Hastanelerde tedavi hizmetleri yanında sunulan otelcilik hizmetlerinin de her geçen gün gelişen teknolojilere ve hasta beklentilerine göre değişmesi gerekmektedir. Sağlığını yeniden kazanmak ve/veya korumak isteyen hastaların ve refakatçilerin konforlu ortamlarda konaklamaları, sağlık otelciliğini hastanelerde zorunlu hale getirmektedir (Hume ve DeMicco, 2007: 76). Bu durum hastane yöneticilerini, sağlık otelciliği hizmetlerini daha iyi sunmaya, hasta, hasta yakını ve personel memnuniyetini artırmaya teşvik etmektedir (Sağlık Bakanlığı, 2015: 10). Nitekim Sağlık Bakanlığı bu amaçla 2012 yılında kendisine bağlı hastanelerde Hasta Hizmetleri ve Sağlık Otelciliği müdürlüğü/birimleri oluşturmuştur (Türkiye Kamu Hastaneleri Kurumu, 2014). Sağlık otelciliği hizmetleri, konaklama ile ilgili olup destek hizmetler niteliğindedir. Destek hizmetler tüm hizmet işletmelerinde önemli bir iş grubunu oluşturmaktadır. Otelcilikteki düzenlemeye benzer şekilde hastanedeki destek hizmetler; temizlik, yiyecek içecek, danışma, çamaşırhane, teknik servis, personel, güvenlik, bahçe/otopark olarak sıralanabilir (Acar, 2014). Hastanelerde bu hizmetlere din (morg), atık toplama, numune taşıma, hasta taşıma gibi hizmetler de eklenmektedir (Türkiye Kamu Hastaneleri Kurumu, 2014). Bu kapsamlı hizmet alanı yöneticileri bu hizmetleri geliştirme ile ilgili çeşitli stratejiler kullanmaya zorlamaktadır. Toplam kalite yönetimi, SWOT analizi, kalite belgeleri, müşteri odaklı yönetim yaklaşımları bunlardan bazılarıdır (Soylu ve İleri, 2010). Daha önce imalat sanayinde tercih edilen örgütsel ustalık yaklaşımı ise son yıllarda hizmet işletmelerinde kullanılmaktadır.

Örgütsel ustalık, mevcut kaynakların etkin kullanımı ile yeni hizmetlerin geliştirilmesini gerektirmesi ve bu iki durumun eş zamanlı kullanımına imkân vermesi bakımından diğer stratejilere göre daha güncel ve kapsamlı bir alternatif stratejidir (Carmeli ve Halevi, 2009: 208). Örgütsel ustalık, ilk olarak 1976 yılında Duncan tarafından ikili örgüt yapılarının birlikte çalıştırılması amacıyla yararlanıcı (mevcut) ve araştırıcı (gelecek) stratejiler kapsamında ortaya atımıştır. 1991'de March tarafından örgütsel öğrenme ile ilişkilendirilmiştir. Son yıllarda ise otel (Şimşek, 2009), hastane (Bodwell, 2011), havayolu şirketleri (Jarvenpaa, 2014), banka (Attar, 2014) ve üniversite (Yılmaz, 2017) gibi hizmet işletmelerinde mevcut duruma dayalı ve geleceğe dönük planlamalarda iç ve dış çevresel koşulları değerlendirmede sıklıkla kullanılan bir yaklaşım haline gelmiştir. Burada bir işletmenin usta olma durumu; yararlanıcı ve araştırıcı stratejileri birlikte uygulayabilme becerisi olarak tanımlanmaktadır. Başka bir ifadeyle, örgütsel ustalık; işletmelerin mevcut işlerini geliştirme ile yeni fırsatlar araştırma yönündeki faaliyetlerini birlikte yürütebilmelerini ifade etmektedir (Cingöz ve Akdoğan, 2014: 65).

Yararlanıcı ve araştırıcı stratejilerin birlikte değerlendirilmesine imkân veren örgütsel ustalık stratejisi bu çalışmada, sağlık otelciliği hizmetleri ile ilişkilendirilmektedir. Bu amaçla, öncelikle hastanelerdeki sağlık otelciliği hizmet düzeyleri ortaya konulmakta; yararlanıcı ve araştırıcı stratejileri kullanma durumları belirlenmektedir. Sonrasında, hastanelerin sağlık otelciliği hizmet düzeyleri ile örgütsel ustalık durumları arasındaki ilişkiler incelenmektedir. 


\section{Alanyazın}

\subsection{Sağlık Otelciliği}

Sağlık otelciliği; ayakta veya yatarak tedavi gören hastalarda, mevcut otelcilik hizmetlerini kullanarak, hasta beklentilerine maksimum düzeyde karşılık verebilme durumunu ifade etmektedir (Sağlık Bakanlığı, 2013: 17). Başka bir deyişle, otelcilik hizmetleri hastanede kalış sürecindeki ağırlama anlamına da gelmektedir. Özellikle, insanların tedavi olurken konforlu ve sağlıklı bir ortamda ağırlanma ihtiyaçları, sağlık otelciliğine olan talebi artırırken, bu hizmetlerin daha özenli ve kaliteli verilmesini gerekli hale getirmektedir. Sağlık otelciliği uygulamalarının, Florence Nightingale'in temiz hasta yatağı, diyet mutfağı, çamaşırhanesi, malzeme deposu bulunan ve hijyen kurallarına uygun hastanelerin kurulmasına öncülük ettiği 1800 'lü yıllarda başladığı görülmektedir (Aktaş, 2007: 20). Bu hizmetler her ne kadar uzun bir geçmişe dayanıyor olsa da günümüz koşullarına uygun hale getirilmesi için sürekli yenilenmesi gerekmektedir. Türkiye'de sağlık otelciliği, Sağlık Bakanlığı tarafından 2012 yılında gündeme getirilmiş ve hizmet sunum rehberinin hazırlanmasından sonra pilot olarak seçilen kamu hastanelerinde uygulanmaya başlanmıştır (Türkiye Kamu Hastaneleri Kurumu, 2014: 9). Bu rehberde, sağlık otelciliği hizmetleri; danışma, hasta kabul, temizlik, atık, yemekhane, güvenlik, hasta/numune taşıma, bahçe/otopark, çamaşırhane, kantin/kafeterya, terzilik, din ve personel olarak 13 kategori altında sınıflandırılmaktadır.

Sağlık otelciliği hizmetleri ile ilgili doğrudan iyileştirme yönlü çalışmalar olmasa da bu kapsamdaki ilk çalışmanın, yiyecek içecek hizmetleri yönetiminde menü planlaması üzerine yapıldığı dikkat çekmektedir. Türkiye'deki hastaneler bağlamında yapılan bu araştırmada, menü planlamasında istenilen titizliğin gösterilmediği ve yiyecek, işgücü ve enerji israfının olduğu tespit edilmiştir (Aktaş, 1985). Ayrıca, bu hastanelerde mutfak düzeni iş akışına tam uymadığı gibi hijyen ve çalışma koşullarının da yeterli olmadığı belirtilmiştir. Özel hastanelerde 'otelcilik' hizmetleri ile ilgili başka bir araştırmada ise kamu hastanelerinden daha kaliteli hizmet sundukları ortaya koyulmuştur (Camilleri ve O'Callaghan, 1998: 131). Aynı sonuç, Türkiye'deki özel hastanelerin kamu hastanelerinden daha başarılı otelcilik hizmetleri verdiklerini ortaya koyan diğer çalışmalarda da görülmektedir (Sevin, 1998; Kılıç, 2002). Hastanelerde sunulan otelcilik hizmetlerinin görsel ve fiziksel (aydınlatma, havalandırma, sıcaklık, koku, sessizlik, dekorasyon vb.) açıdan daha çekici olması (Aşıkoğlu, 2014: 127); oda servisi, hediyelik eşya ve kuaför salonları gibi hizmetlere yer verilmesi, son yıllardaki hasta beklentileri ile ilgili araştırmalarda dile getirilmektedir (Rosenthal, 2013). Ancak hastanelerde bu hizmetlerin artırılmasına bağlı olarak maliyetlerin yükseldiğine dair eleştirel görüşler de bulunmaktadır (Sheehan-Smith, 2006: 585).

\section{2. Örgütsel Ustalık}

Örgütsel ustalık; bir işletmede çalışanların gelecekteki durumlara karşı hazırlıklı olma ve bugünün faaliyetlerini de yönetebilme yeteneği olarak ifade edilmektedir (Birkinshaw ve Gibson, 2004: 49). Han ve Celly (2008: 336) örgütsel ustalığı, yararlanıcı strateji ve araştırıcı strateji olarak kabul gören iki stratejiyi birlikte uygulayabilme yeteneği olarak tanımlamaktadır. Yararlanıcı strateji; mevcut bilgi, yetenek ve süreci geliştirme ve daha ileriye götürme olarak tanımlanmaktadır. Bu strateji kapsamında, mevcut durumla ilgili üretim, verimlilik, etkenlik, geliştirme, seçim ve uygulamalar ele alınmaktadır. Araştırıcı strateji ise yeni bilgi, yetenek ve sürecin keşfedilip araştırılması olarak tanımlanmaktadır. Bu stratejiyi daha iyi açıklamak için araştırma, çeşitlilik, risk alma, farklı düşünme, özerklik, esneklik, keşif ve yenilik kavramlarından yararlanılmaktadır 
(March, 1991: 71). Bu bağlamda, örgütsel ustalığın felsefi temeli; karşıtların birlikteliğini savunan postmodern bir anlayışa dayandırılabilir. Çünkü zıt pozisyonların yan yana gelmesi postmodernizmde tipik bir olgu olarak ele alınmaktadır (Özcan, 2012: 45).

Yararlanıcı ve araştırıcı stratejinin bipolarliki uçlu ya da ortogonalldikey olduğuna dair iki farklı görüş bulunmaktadır. Bipolar yaklaşım, bir stratejiyi diğerine tercih etmeyi, birine yaklaşırken diğerinden uzaklaşmayı varsaymaktadır (Bodwell, 2011: 44). Bu varsayım ile hareket edildiğinde örgütsel ustalık değerine, yararlanıcı ve araştırıcı stratejiler arasındaki farkın mutlak değeri hesaplanarak ulaşılmaktadır. Aralarındaki fark ne kadar az ise örgüt o derece yüksek seviyede usta örgüt olarak adlandırılmaktadır (Şanal, 2013: 27). Ortogonal yaklaşım ise iki stratejinin birbirinin tamamlayıcısı olduğu varsayımına dayanmaktadır (Bodwell, 2011: 44). Buna göre her iki strateji arasındaki ilişki dikey olarak kabul edilmekte ve iki stratejinin çarpımı şeklinde hesaplanmaktadır. Bu etkileşim (çarpım değeri), ne kadar yüksekse örgütsel ustalık o kadar yüksektir (Gupta ve diğ., 2006: 696). Örgütsel ustalık ile ilgili çalışmalara bakıldığında, özellikle yararlanıcı ve araştıııcı strateji arasındaki korelasyonun yüksek olması tercih edilmektedir. Bu durum, örgütlerin, yararlanıcı ve araştırıcı stratejiyi aynı anda kullandığını ve ustalık düzeyinde olduğunu göstermektedir (Gibson ve Birkinshaw, 2004: 220; Bierly ve Daly, 2007: 506; Attar, 2014: 116; Yılmaz, 2017: 134).

\subsection{Sağlık Otelciliği ve Örgütsel Ustalık İlişkisi}

Hastanelerde örgütsel ustalık ile kalite ve finansal performans ilişkisinin ele alındığı Bodwell'in (2011: 149) çalışmasında, araştırma bulguları hem yararlanıcı hem de araştırıcı stratejiler ile finansal performans ve kalite arasında güçlü ve pozitif ilişki olduğunu ortaya koymaktadır. Sonraki dönemlerde hastanelerin örgütsel ustalık durumları ile bilgi yönetimi konusundaki yetenekleri arasındaki ilişkinin araştırıldığı başka bir çalışmada, hastanelerin örgütsel ustalık durumlarının bilgi yönetmedeki yeteneklerini olumlu yönde etkilediği sonucuna ulaşılmıştır (Burgess ve diğ., 2015: 87). Bu bağlamda yürütülen Malik ve diğerlerinin (2017: 1359) çalışmalarında, hastanelerde destek hizmetlerde yararlanıcı stratejinin tercih edildiği; tanı, tedavi, risk yönetimi ve süreç iyileştirmeleri gibi uygulamalarda ise araştırıcı stratejinin gerekli olduğu ortaya koyulmuştur. Ancak yararlanıcı ve araştırıcı stratejilerin zamanlamasının bu süreçte önemli olduğunu vurgulayan çalışmalar da bulunmaktadır. Greenhut ve diğerleri (2017: 1), bu amaçla yeni bir geçiş modeli önermişlerdir. Bu modelde iki strateji arasındaki geçişin dinamik, kısa süreli olduğu gözlenmiş ve bu iki stratejinin bir hastanede aynı anda uygulanabileceği sonucuna ulaşılmıştır. Aynı şekilde, Koster ve Van Bree'nin (2018: 2) çalışmalarında, örgütsel ustalığın yönetilen bir süreç olduğu ve bu süreçte organizasyonların usta örgüt olmak için yararlanıcı stratejiden araştırıcı stratejiye geçiş yaptıkları belirlenmiştir. Gastaldi ve diğerlerinin (2018: 2) yürüttükleri çalışmada ise sağlık hizmetlerinde, yararlanıcı ve araştırıcı stratejiler arasındaki geçişlerin dengelenmesi için hastanelerde bulunan dijital varlıkların önemli ve tamamlayıcı roller (maliyet düşürme, kalite iyileştirme vb.) üstlendikleri saptanmıştır.

Türkiye'deki hastanelerde yararlanıcı ve araştırıcı stratejilerin kullanımının daha önceki yıllarda başlamış olması dikkat çekicidir. Özellikle, kamu sektöründeki hastanelerin mevcut faaliyetlere (yararlanıcı) odaklandıkları, özel sektördeki hastanelerin ise yenilikçi (araştırıcı) stratejileri kullandığı bu bağlamda ortaya çıkan öncül bulgular olarak dikkat çekmektedir (Akbolat, 2009: 144). Sonraki yıllarda, Doğan ve diğerlerinin (2017: 817) yaptıkları çalışmada, hastane yöneticilerine; insan kaynaklarının seçimi, eğitimi, çalışan bağlılığı, liderlik konularında verimlilik esaslı bir stratejinin (yararlanıcı stratejiye dayalı) kullanımı önerilirken; sürekli iyileştirme, 
hastane bilgi sistemi, hizmet kültürü alanında yapılacak farklılaştırma çalışmalarında ise araştırıcı stratejinin kullanımı önerilmektedir.

Görüldüğü gibi hastanelerde örgütsel ustalık konusu yararlanıcı ve araştırıcı stratejiler kapsamında farklı şekillerde ele alınmıştır. Bu araştırmalar göstermektedir ki örgütsel ustalık için bu stratejilerin birbirinin tamamlayıcısı (ortogonal yaklaşım) olması tercih edilmektedir. Bu çalışmada ise hastanelerde uygulanan sağlık otelciliği hizmetleri ile örgütsel ustalık ilişkisinin belirlenmesinde ortogonal yaklaşım benimsenerek, yararlanıcı ve araştırıcı stratejiler birlikte kullanılmıştır. $\mathrm{Bu}$ amaçla oluşturulan araştırmanın hipotezleri ve modeli şu şekildedir:

$H_{1}$ : Hastanelerde sağlık otelciliği hizmetleri ile yararlanıcı strateji arasında pozitif bir ilişki vardır.

$\mathrm{H}_{2}$ : Hastanelerde sağlık otelciliği hizmetleri ile araştırıcı strateji arasında pozitif bir ilişki vardır.

Şekil 1: Araştırma Modeli

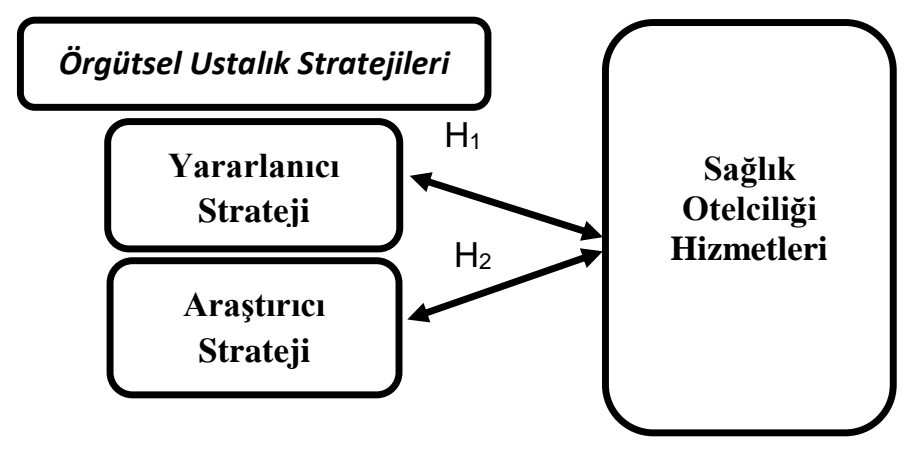

\section{Araştırmanın Yöntemi}

$\mathrm{Bu}$ çalışmada, öncelikle sağlık otelciliği ve örgütsel ustalık ile ilgili alanyazın incelenmiştir. Bu incelemeler sonrasında, sağlık otelciliği hizmetlerinin iyileştirilmesinde örgütsel ustalık kuramından yararlanılmasına karar verilmiştir. Çalışma, nicel yaklaşımla kurgulanmıştır. Bu amaçla, anket tekniğinden yararlanılmıştır. Anket formu iki ölçek şeklinde düzenlenmiştir. Birinci ölçek; Sağlık Otelciliği Hizmet Sunum Rehberinde yer alan 13 kategori (danışma, hasta kabul, temizlik, atık, yemekhane, güvenlik, hasta/numune taşıma, bahçe/otopark, çamaşırhane, kantin/kafeterya, terzilik, din ve personel) ve 160 ifadeden oluşmaktadır. Hastanelerde görev yapan 6 yönetici ve ilgili alanda uzman 6 kişiden oluşan bir grupla yapılan değerlendirmeler doğrultusunda ölçeğin kapsam geçerliliğinin belirlenmesi için Lawshe tekniği uygulanmıştır. Bu teknikte; 12 uzman sayısı için $\alpha=0,05$ anlamlılık düzeyinde minimum Kapsam Geçerlilik Oranı ${ }^{1}$ (KGO) değeri, 0,56 olarak belirlenmiştir (Lawshe, 1975: 568; Şencan, 2005: 754). Uzman görüşlerinden sonra düşük kapsam geçerlilik oranına (0,56'dan küçük) sahip olan ifadeler ölçekten çıkarılmıştır. Böylece Sağlık Otelciliği Ölçeği, 9 kategori ve 58 ifade olarak yeniden düzenlenmiştir. Anket formunda yer alan ikinci ölçek ise Bodwell (2011) tarafından hastanelere uyarlanan ve toplam 16 ifadeden

${ }^{1}$ Kapsam Geçerlilik Oranının hesaplanmasında kullanılan formül, $K G O=\frac{n_{e}-\frac{N}{2}}{\frac{N}{2}}$ şeklinde gösterilmektedir. $\mathrm{Bu}$ formülde, $n_{e}$ ifadenin uygun olduğunu belirten uzman sayısını, $\mathrm{N}$ toplam uzman sayısını ifade etmektedir. 
(ilk 8 ifade araştırıcı strateji; diğer 8 ifade yararlanıcı strateji) oluşan Örgütsel Ustalık Ölçeğidir.

Bu araştırmanın yürütüldüğü Aralık 2016-Mart 2017 tarihleri arasında Ankara'da 86 devlet hastanesi, 27 özel hastane ve 10 üniversite hastanesi hizmet vermektedir (Ankara İ Sağlık Müdürlüğü, 2016). Bu hastanelerden amaçlı örnekleme tekniğiyle seçilen ve gerekli yasal izinlerin (Devlet hastaneleri için Ankara 1. Bölge Kamu Hastaneleri Genel Sekreterliğine, üniversite ve özel hastaneler için hastane başhekimliklerine) alınabildiği üç hastanede gerçekleştirilmiştir. Bu hastanelerdeki yöneticilere (müdür, müdür yardımcıları, şefler) ve idari çalışanlara (muhasebe, sekreter, halkla ilişkiler, alt birim sorumluları, bilgi iş̧lem ve sağlık otelciliği hizmetlerinde çalışan tüm destek hizmetler personeli) yüz yüze ve bırak topla şeklinde anket uygulanmıştır. Hastanelerden ulaşılan anket sayılarına Tablo 1'de yer verilmektedir.

Tablo 1: Hastanelerdeki Anket Dağılımı

\begin{tabular}{|l|c|c|c|c|}
\hline \multicolumn{1}{|c|}{ Hastaneler } & $\begin{array}{c}\text { Doktor ve Sağlık } \\
\text { Personeli hariç } \\
\text { Idari Çalışan Sayısı }\end{array}$ & $\begin{array}{c}\text { Toplam } \\
\text { içindeki } \\
\text { ağırlığı (\%) }\end{array}$ & $\begin{array}{c}\text { Önerilen } \\
\text { Örneklem } \\
\text { Büyüklüğü }\end{array}$ & $\begin{array}{c}\text { Ulaşılan } \\
\text { Anket } \\
\text { Sayısı }\end{array}$ \\
\hline Devlet Hastanesi & 2400 & 53,38 & 309 & 315 \\
\hline $\begin{array}{l}\text { Üniversite } \\
\text { Hastanesi }\end{array}$ & 1778 & 39,54 & 228 & 252 \\
\hline Özel Hastane & 318 & 7,07 & 40 & 105 \\
\hline Genel Toplam & $\mathbf{4 4 9 6}$ & $\mathbf{1 0 0}$ & $\mathbf{5 7 9}$ & $\mathbf{6 7 2}$ \\
\hline
\end{tabular}

Not: Hastaneler ile ilgili bilgiler yetkili kişilerinden alınmıştır.

$\mathrm{Bu}$ çalışmanın evrenini 4496 hastane personeli oluşturmaktadır. Evren büyüklüğü $(N)$ biliniyorsa örneklem büyüklüğü $n=\left(N t^{2} p q\right) /\left(d^{2}(N-1)+t^{2} p q\right)$ formülü kullanılarak hesaplanmaktadır. 4496 kişilik evren büyüklüğüne $\pm \% 05$ kabul edilebilir hata ile \%95 güven seviyesinde örneklem büyüklügünün 354, \%98 güven seviyesinde örneklem büyüklüğünün 484, \%99 güven seviyesinde örneklem büyüklüğünün 579 olması önerilmektedir (Ural ve Kılıç, 2013: 45). Bu doğrultuda, dağıtılan 1200 anketten; devlet hastanesinden 315, üniversite hastanesinden 252 ve özel hastaneden 105 olmak üzere toplamda 672 geçerli anket elde edilmiş ve anket geri dönüş oranı $\% 55,1$ olarak gerçekleşmiştir (Tablo 1).

Elde edilen verilerin normal dağılıma sahip olup olmadığını belirlemek için Shapiro-Wilk testi yapılmıştır. Normallik (Shapiro-Wilk) Testi sonucuna göre verilerin $p$ değerleri $(p<0,001)$, istatistiksel anlamlılık düzeyi olarak kabul edilen 0,05 'ten küçük olduğu için, incelenen verilerin dağılımlarının normal olmadığı sonucuna ulaşılmıştır (Tablo 2). Ayrıca, ölçeklerin güvenilirlik analizi sonuçlarına göre Sağlık Otelciliği Ölçeğinin iç tutarlılık katsayısının (Cronbach Alpha) ,976; Örgütsel Ustalık Ölçeğinin ise iç tutarlılık katsayısının ,946 olduğu tespit edilmiştir. Ölçekler için $\alpha=0,700$ üstü katsayısı değerleri yüksek güvenirlik olarak kabul edilmektedir (Alpar, 2011).

Tablo 2: Normallik Testi Sonuçları

\begin{tabular}{lcc}
\hline \multirow{2}{*}{ Ölçek Adı } & \multicolumn{2}{c}{ Shapiro Wilk } \\
\cline { 2 - 3 } & Test İstatistiği & $\mathbf{p}$ \\
\hline Sağlık Otelciliği Ölçeği &, 994 &, 000 \\
\hline Örgütsel Ustalık Ölçeği &, 987 &, 000 \\
\hline
\end{tabular}


Hastane çalışanlarına ait demografik bilgilerin belirlenmesi, hastanelerde uygulanan örgütsel ustalık stratejilerinin neler olduğu ve sağlık otelciliği hizmetlerinin ne düzeyde yeterli sunulduğunun belirlenmesine yönelik betimsel istatistiklerden (frekans, yüzde, aritmetik ortalama ve standart sapma) yararlanılmıştır. Betimsel istatistiklerde ölçeklerin aralık genişliği, "dizi genişliği/yapılacak grup sayısı" formülünden yararlanılarak $4 / 5=, 80$ olarak hesaplanmıştır (Tekin, 1993). Buna göre araştırma bulgularının değerlendirilmesinde esas alınan aritmetik ortalama aralıkları; sağlık otelciliği ölçeğinde 1,00-1,79 "Tamamen Yetersiz", 1,80-2,59 "Yetersiz", 2,603,39 "Kısmen Yeterli", 3,40-4,19 "Yeterli", 4,20-5,00 "Tamamen Yeterli" şeklinde yorumlanmıştır. Örgütsel ustalık ölçeğinde ise 1.00-1.79 "Tamamen Katılmıyorum", 1,80-2,59 "Katılmıyorum", 2,60-3,39 "Ne Katılıyorum Ne Katılmıyorum", 3,40-4,19 "Katılıyorum", 4,20-5,00 "Tamamen Katılıyorum" olarak değerlendirilmiştir.

Sağlık otelciliği hizmetleri ile örgütsel ustalık stratejileri arasındaki ilişkilerin test edilmesi amacıyla korelasyon analizi yapılmıştır. Korelasyon katsayısı 0,29'dan küçük ise ilişkinin düşük/zayıf, 0,30 ile 0,64 arasında ise orta, 0,65-0,84 arasında ise yüksek/kuvvetli, 0,85 'den büyük ise ilişkinin çok yüksek/çok kuvvetli olduğu kabul edilmektedir (Ural ve Kılıç, 2013: 244). Bu araştırmada kullanılan korelasyon katsayısı ise Spearman sıra korelasyon katsayısıdır. Pearson korelasyon katsayısının parametrik olmayan alternatifi olarak görülen bu katsayı, değişkenlerin en az aralık veya oran ölçeği ile ölçülemediği ve değişkenlerden birinin ya da ikisinin birlikte normal dağılmadığı durumlarda tercih edilmektedir (Lorcu, 2015: 239).

\section{Bulgular ve Tartışma}

Çalışma bulguları; demografik bilgiler, sağlık otelciliği, örgütsel ustalık ve ilişki analizleri olmak üzere dört ayrı başlık altında sunulmaktadır.

\subsection{Demografik Bilgiler}

Hastane çalışanlarına ait demografik bilgilere Tablo 3'te yer verilmektedir. Buna göre çalışanlar ağılıklı olarak devlet hastanesinde $(\% 46,8)$ görev yapmaktadır. Bunu üniversite hastanesinde $(\% 37,5)$ ve özel hastanede $(\% 15,6)$ çalışanlar takip etmektedir. Her üç hastanede kadın çalışanlar görece erkek çalışanlardan fazladır. Dolayısıyla, hastanelerdeki sağlık otelciliği hizmetleri ile otellerdeki kadın emeğine dayalı olma özelliği benzerlik göstermektedir (Aksu ve diğ., 2016: 68). Yaş gruplarına göre devlet hastanesinde $(\% 26,3)$ ve özel hastanede $(\% 32,4)$ yoğunluk 37-42 yaş grubunda iken; üniversite hastanesinde yoğunluğun 43 yaş ve üzeri (\%34,1) yaş grubunda olduğu dikkat çekmektedir. Bu durum her üç hastanede sağlık otelciliği hizmetlerinde çalışan profilinin orta yaş ve üzeri yaş grubunda olduğunu göstermektedir. Eğitim düzeyleri dikkate alındığında, devlet hastanesinde $(\% 32,4)$ ve özel hastanede $(\% 30,5)$ lisans mezunu çalışanlar ağırlıklı iken; üniversite hastanesinde $(\% 33,3)$ lise mezunu çalışanların fazla olduğu görülmektedir. Yönetici dağılımı incelendiğinde, özel hastane $(\% 7,4)$ ilk sırada, üniversite hastanesi $(\% 3,2)$ ikinci sırada, devlet hastanesi (\%2) ise üçüncü sıradadır. Çalışma sürelerine bakıldığında, 11 yıl ve daha az deneyime sahip çalışanların $(\% 68,9)$; üniversite hastanesinde 12 yıl ve daha fazla deneyime sahip çalışanların $(\% 56,4)$; özel hastanede ise 7 yıl ve daha az deneyimi olan çalışanların $(\% 58,1)$ yoğun olduğu görülmektedir. Araştırmaya dahil edilen özel hastanede çalışanların 7 yıl ve daha az deneyimli olması, bu hastanenin 8 yıllık hizmet süresine bağlanabilir. Üç hastane karşılaştırıldığında, üniversite hastanesi çalışanlarının diğer iki hastane çalışanlarına göre daha deneyimli olduğu ortaya çıkmaktadır. Bu profil bilgilerine dayanarak, sağlık otelciliği hizmetlerinde çalışanların yaş, eğitim ve mesleki deneyim itibariyle yeterli olgunluk düzeyinde olduğu söylenebilir. 
Tablo 3: Katılımcıların Demografik Bilgileri

\begin{tabular}{|c|c|c|c|c|c|c|}
\hline \multirow{2}{*}{ Değişkenler } & \multicolumn{2}{|c|}{ Devlet Hastanesi } & \multicolumn{2}{|c|}{ Üniversite Hastanesi } & \multicolumn{2}{|c|}{ Özel Hastane } \\
\hline & f & $\%$ & f & $\%$ & $f$ & $\%$ \\
\hline \multicolumn{7}{|l|}{ Cinsiyet } \\
\hline Kadın & 180 & 57,1 & 136 & 54 & 62 & 59 \\
\hline Erkek & 135 & 42,9 & 116 & 46 & 43 & 41 \\
\hline Toplam & 315 & 100 & 252 & 100 & 105 & 100 \\
\hline \multicolumn{7}{|l|}{ Yaş } \\
\hline $19-24$ yaş arası & 14 & 4,4 & 10 & 4 & 10 & 9,5 \\
\hline $25-30$ yaş arası & 74 & 23,5 & 32 & 12,7 & 21 & 20 \\
\hline $31-36$ yaş arası & 78 & 24,8 & 59 & 23,4 & 26 & 24,8 \\
\hline $37-42$ yaş arası & 83 & 26,3 & 65 & 25,8 & 34 & 32,4 \\
\hline 43 yaş ve üstü & 66 & 21 & 86 & 34,1 & 14 & 13,3 \\
\hline Toplam & 315 & 100 & 252 & 100 & 105 & 100 \\
\hline \multicolumn{7}{|l|}{ Eğitim } \\
\hline İlkokul & 20 & 6,3 & 10 & 4 & 15 & 14,3 \\
\hline Ortaokul & 23 & 7,3 & 21 & 8,3 & 6 & 5,7 \\
\hline Lise & 77 & 24,4 & 84 & 33,3 & 21 & 20 \\
\hline Önlisans & 62 & 19,7 & 51 & 20,2 & 30 & 28,6 \\
\hline Lisans & 102 & 32,4 & 76 & 30,2 & 32 & 30,5 \\
\hline Lisansüstü & 31 & 9,8 & 10 & 4 & 1 & 1 \\
\hline Toplam & 315 & 100 & 252 & 100 & 105 & 100 \\
\hline \multicolumn{7}{|l|}{ Görev } \\
\hline Müdür & 1 & 0,4 & 1 & 0,4 & 1 & 0,9 \\
\hline Müdür Yard. & 2 & 0,6 & - & - & 1 & 0,9 \\
\hline Şef & 3 & 1 & 7 & 2,8 & 3 & 3 \\
\hline İdari Personel & 309 & 98 & 244 & 96,8 & 100 & 95,2 \\
\hline Toplam & 315 & 100 & 252 & 100 & 105 & 100 \\
\hline \multicolumn{7}{|c|}{ Mesleki Deneyim } \\
\hline $1-3$ yıl & 62 & 19,7 & 31 & 12,3 & 26 & 24,8 \\
\hline $4-7$ yıl & 85 & 27 & 32 & 12,7 & 35 & 33,3 \\
\hline 8-11 yıl & 70 & 22,2 & 47 & 18,6 & 19 & 18,1 \\
\hline $12-15$ yıl & 50 & 15,9 & 49 & 19,5 & 14 & 13,3 \\
\hline 16 yıl ve üstü & 48 & 15,2 & 93 & 36,9 & 11 & 10,5 \\
\hline Toplam & 315 & 100 & 252 & 100 & 105 & 100 \\
\hline
\end{tabular}

\subsection{Sağlık Otelciliği}

$\mathrm{Bu}$ kısımda, öncelikle sağlık otelciliği ile ilgili bulgulara yer verilmektedir. Sağlık otelciliği hizmetlerinin daha önce belirlenmiş olan 13 kategorisi bu araştırmada 9'a indirilmiştir. Bu kategoriler şöyle sıralanabilir; danışma, güvenlik/numune taşıma, temizlik, atık, yemekhane/kantin-kafeterya, çamaşırhane/terzilik, bahçe-otopark, din ve personel. Bu kategoriler ve alınan değerlere Tablo 4'te yer verilmektedir.

Tablo 4'te görüldüğü üzere; devlet hastanesinde, güvenlik/numune taşıma hizmetleri en yüksek ortalama ile temsil edilirken; en düşük ortalamanın bahçe-otopark hizmetlerinde olduğu belirlenmiştir. Devlet hastanesindeki sağlık otelciliği hizmetlerinin ortalama değerleri 3,18 ile 2,62 arasında değişmektedir. Bu durum, sağlık otelciliği hizmetlerinin devlet hastanesinde kısmen yeterli düzeyde sunulduğunu göstermektedir. Bu bulgu önceki çalışmalarla (Korkmazer ve diğ., 2016; Şantaş ve diğ., 2017) benzerlik göstermektedir. Buna göre güvenlik hizmetlerine ilişkin "renkli kod ve acil çağrılara zamanında ulaşılması", "bina güvenliğine yönelik tedbirlerin alınması", "güvenlik 
sistemlerinin hazırlanması" ile ilgili konuların iyileştirilmesi ve geliştirilmesi gerektiği söylenebilir. Bu hizmetin taşeron firmadan sağlanması eksik hizmet algısına sebep olmuş olabilir (Söyler ve Zekioğlu, 2017: 18).

Tablo 4: Katılımcıların Sağlık Otelciliği Hizmetleri Hakkındaki Görüşleri

\begin{tabular}{|l|c|c|c|c|c|c|}
\hline \multirow{2}{*}{ Sağlık Otelciliği Hizmetleri } & \multicolumn{2}{|c|}{$\begin{array}{c}\text { Devlet } \\
\text { Hastanesi } \\
\text { (n=315) }\end{array}$} & \multicolumn{2}{c|}{$\begin{array}{c}\text { Üniversite } \\
\text { Hastanesi } \\
(\mathbf{n = 2 5 2})\end{array}$} & \multicolumn{2}{c|}{$\begin{array}{c}\text { Özel } \\
\text { Hastane } \\
(\mathbf{n = 1 0 5 )}\end{array}$} \\
\cline { 2 - 7 } & Ort. & S.S. & Ort. & S.S. & Ort. & S.S. \\
\hline 1. Danışma & 3,03 & 0,76 & 3,16 & 0,70 & 4,15 & 0,51 \\
\hline 2. Güvenlik/Numune Taşıma & 3,18 & 0,81 & 3,19 & 0,72 & 4,21 & 0,51 \\
\hline $\begin{array}{l}\text { 3.Yemekhane/Kantin- } \\
\text { Kafeterya }\end{array}$ & 3,03 & 0,79 & 3,21 & 0,61 & 4,08 & 0,48 \\
\hline 4. Temizlik & 3,00 & 0,85 & 3,37 & 0,68 & 4,18 & 0,51 \\
\hline 5. Çamaşırhane/Terzilik & 2,80 & 0,91 & 3,55 & 0,71 & 4,23 & 0,51 \\
\hline 6. Atık & 3,02 & 0,95 & 3,75 & 0,80 & 4,26 & 0,55 \\
\hline 7. Din & 3,13 & 0,90 & 3,82 & 0,74 & 4,36 & 0,48 \\
\hline 8. Bahçe-Otopark & 2,62 & 1,02 & 3,21 & 0,90 & 3,85 & 0,91 \\
\hline 9. Personel & 3,15 & 0,76 & 3,23 & 0,65 & 3,92 & 0,53 \\
\hline Toplam & $\mathbf{2 , 9 9}$ & $\mathbf{0 , 6 9}$ & $\mathbf{3 , 3 6}$ & $\mathbf{0 , 5 1}$ & $\mathbf{4 , 1 2}$ & $\mathbf{0 , 3 9}$ \\
\hline
\end{tabular}

Bahçe-otopark hizmetlerinin devlet hastanesinde kısmen yeterli olma durumu da önceki çalışmalarla (Selim, 2011; Sakıcı ve diğ., 2013) benzer niteliktedir. Bu hizmetlerin orta düzeyde olması; "engelliler", "hastalar" ve "personel" için ayrı otopark alanlarının olmamasına, "bahçe, otopark ve yürüme alanlarının aydınlatma yetersizliğine", "yönlendirme" ve "yaya güvenliği" ile ilgili düzenlemelerin inmal edildiğine bağlanabilir. Demir (2015) tarafından yapılan bir çalışmada, yeşil alanların bakımsızlığı ve yetersizliği, engelli ve tekerlekli sandalye kullanımına yönelik düzenlemelerin kısıtlılığı kamu hastanelerinde karşılaşılan temel eksiklikler olarak belirlenmiştir. Hastanelerin, şehirlerin hızlı büyümesi sonucunda zamanla trafiği yoğun alanlar içinde kalması ve kent merkezinde açılan yeni hastanelerin otopark için ayrılan alanlarının dar olması araştırma kapsamındaki devlet hastanesinde de otopark sorununu başat sorun olarak gündeme getirmiştir.

Üniversite hastanesinde sağlık otelciliği hizmetleri arasında din hizmetleri yüksek bir ortalama ile ilk sırada yer alırken, danışma hizmetleri en düşük ortalama ile son sırada yer almıştır. Üniversite hastanesindeki sağlık otelciliği hizmetleri ortalaması ise 3,82 ile 3,16 arasındadır. Din, atık ve çamaşırhane/terzilik hizmetlerinin yeterli düzeyde olduğu görülmektedir. Danışma, güvenlik, yemekhane/kantin-kafeterya, temizlik, bahçe-otopark ve personel hizmetleri ise kısmen yeterli düzeyde bulunmuştur. Bu bulgular, hastanelerde din (morg) hizmetlerinin yeterli olduğunu gösteren, Güden ve diğerlerinin (2010) çalışmasını desteklemektedir. Söz konusu çalışmada da morg hizmetlerinin 2007 yılında \%87,5 oranında yeterli düzeyde sunulurken, 2009 yılında \%100 yeterliliğe ulaştığını saptamıştır. Üniversite hastanesinde "adli vakalardaki resmi prosedürleri", "bulaşıcı hastalıklardan ölenlerin defin işlemleri", "morgdaki mevtaların korunması ve tüm kayıt işlemleri" ile ilgili hizmetlerin yeterli düzeyde sunulduğu belirlenmiştir.

Danışma hizmetleri üniversite hastanesinde kısmen yeterli düzeyde bulunmuştur. Bu durum daha önce yapılan çalışmalarda da görülmektedir (Zaim ve Tarım, 2010; Taşlıyan ve Gök, 2012). Bu hizmet kategorisinde, üniversite hastanesinde şu konuların daha iyi hale getirilmesi gerekmektedir: "Danışmada 
hastaneye ait broşür bulundurulması," "yaşlı ve engelli hastaların işlemlerine intiyaç halinde eşlik edilmesi", "belirlenen ziyaret saatlerine riayet edilmesi", "veri girişlerinin tam ve doğru yapılması". Özellikle, hasta yoğunluğu ile bağlantılı bir istihdam politikasının olmaması, gelişigüzel personel alımları gibi nedenlerle, hizmetin kalitesi olumsuz algılanabilmektedir (Güllüpunar, 2016).

Özel hastanede en yüksek ortalama din hizmetlerindedir. En düşük ortalama ise bahçe-otopark hizmetlerinde saptanmıştır. Hesaplanan ortalamalar 4,36 ile 3,85 arasında değişmekte ve güvenlik, çamaşırhane/terzilik, atık ve din hizmetleri tamamen yeterli düzeyde algılanmaktadır. Danışma, yemekhane/kantin-kafeterya, temizlik, bahçe-otopark ve personel hizmetlerinin de yeterli düzeyde sunulduğu görülmektedir.

Üç hastanenin sağlık otelciliği hizmet durumları değerlendirildiğinde, ilk sırada özel hastane $(\% 82,4)$ yer alırken, bu sıralamayı üniversite hastanesi $(\% 67,4)$ ve devlet hastanesi $(\% 59,8)$ izlemektedir. Buna göre sağlık otelciliği hizmetlerinde özel hastanenin yeterli düzeyde olduğu; üniversite hastanesi ve devlet hastanesinin ise kısmen yeterli düzeyde olduğu söylenebilir.

\section{3. Örgütsel Ustalık}

Sağlık otelciliğinin başarısı için önerilen örgütsel ustalık ve ilgili stratejilerin kullanım durumuna yönelik bulgulara Tablo 5'te yer verilmektedir.

Tablo 5: Örgütsel Ustalık Stratejileri Hakkında Katılımcıların Görüşleri

\begin{tabular}{|l|c|c|c|c|c|c|}
\hline \multirow{2}{*}{$\begin{array}{c}\text { Örgütsel Ustalık } \\
\text { Stratejileri }\end{array}$} & \multicolumn{2}{c|}{$\begin{array}{c}\text { Devlet } \\
\text { Hastanesi (n=315) }\end{array}$} & \multicolumn{2}{c|}{$\begin{array}{c}\text { Üniversite } \\
\text { Hastanesi (n=252) }\end{array}$} & \multicolumn{2}{c|}{$\begin{array}{c}\text { Özel } \\
\text { Hastane (n=105) }\end{array}$} \\
\cline { 2 - 7 } & Ort. & S.S. & Ort. & S.S. & Ort. & S.S. \\
\hline Yararlanıcı Strateji & 2,97 & 0,84 & 3,13 & 0,70 & 3,80 & 0,68 \\
\hline Araştırıcı Strateji & 2,74 & 0,89 & 2,80 & 0,72 & 3,73 & 0,76 \\
\hline $\begin{array}{l}\text { Yararlanıcı ve AraştırıCı } \\
\text { Etkileşimi }{ }^{*}\left(X_{(Y S . A S)}\right)\end{array}$ & 8,14 & 3,86 & 8,76 & 2,87 & 14,17 & 7,41 \\
\hline
\end{tabular}

*Örgütsel ustalık stratejilerinden yararlanıcı ve araştırıcı etkileşimi (çarpım değeri); $\left(\bar{X}_{(Y S . A S)}\right)$ şeklinde formüle edilmiştir.

Tablo 5'e bakıldığında, örgütsel ustalık stratejileri açısından, yararlanıcı stratejiyi kullanma eğilimi, devlet ve üniversite hastanesinde orta düzeyde iken, özel hastanede yüksek düzeydedir. Araştırıcı strateji kullanımı ise özel hastane yüksek düzeyde iken; devlet hastanesinde ve üniversite hastanesinde orta düzeydedir. Yararlanıcı stratejinin her üç hastanede de daha çok kabul görmesi; bu stratejinin işletme performansı üzerinde daha kısa dönemde fayda sağlamasıyla ilişkili olabilir (Bierly ve Daly, 2007; Tutar ve diğ, 2017). Burada özel hastanenin araştırıcı stratejiyi kullanmada daha başarılı olduğu dikkat çekmektedir.

Yararlanıcı ve araştırıcı stratejilerin birlikte kullanıldığını gösteren etkileşim değeri $\left(\bar{X}_{(Y S . A S)}\right)$ örgütsel ustalığın en önemli göstergesi olarak ele alınmaktadır. Buna göre yararlanıcı ve araştırıcı stratejileri birlikte kullanmada, başka bir deyişle ustalık durumunda, özel hastanenin ilk sırada yer aldığı, bunu üniversite hastanesi ve sonrasında devlet hastanesinin izlediği görülmüştür. Örgütsel ustalık için yararlanıcı ve araştırıcı stratejiler arasındaki etkileşim değeri ve korelasyon değerlerine Tablo 6'da yer verilmektedir. 
Tablo 6: Yararlanıcı ve Araştırıcı Strateji İlişkisi

\begin{tabular}{|c|c|c|c|c|c|c|c|c|c|c|}
\hline \multirow{2}{*}{$\begin{array}{l}\text { Örgütsel } \\
\text { Ustalık } \\
\text { Stratejileri }\end{array}$} & \multirow{2}{*}{ 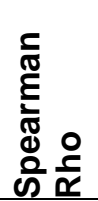 } & \multicolumn{3}{|c|}{$\begin{array}{c}\text { Devlet } \\
\text { Hastanesi }(n=315)\end{array}$} & \multicolumn{3}{|c|}{$\begin{array}{c}\text { Üniversite } \\
\text { Hastanesi }(n=252)\end{array}$} & \multicolumn{3}{|c|}{$\begin{array}{c}\text { Özel } \\
\text { Hastane }(n=105)\end{array}$} \\
\hline & & 1 & 2 & 3 & 1 & 2 & 3 & 1 & 2 & 3 \\
\hline $\begin{array}{l}\text { 1.Yararlanıcı } \\
\text { Strateji }\end{array}$ & $r$ & 1 & - & - & 1 & - & - & 1 & - & - \\
\hline \begin{tabular}{|l|} 
2.Araştırıcı \\
Strateji
\end{tabular} & $r$ & ,700 & 1 & - & ,726 & 1 & - & ,737 & 1 & - \\
\hline 3.Etkileşim & $r$ & ,920 & ,918 & 1 & ,935 & 914 & 1 & 940 & ,923 & 1 \\
\hline
\end{tabular}

Tablo 6'da görüldüğü gibi yararlanıcı ve araştırıcı stratejiler arasında devlet hastanesinde $(r=, 700)$, üniversite hastanesinde $(r=, 726)$ ve özel hastanede $(r=, 737)$ pozitif ve yüksek düzeyde bir ilişki tespit edilmiştir. Bu durum, hastanelerde her iki stratejinin birlikte başarılı bir şekilde kullanıldığını göstermektedir. Bu iki strateji arasındaki pozitif ilişki, aynı zamanda yararlanıcı strateji ile araştıııcı stratejinin birbirinin tamamlayıcısı olma özelliğine de işaret etmektedir (Gupta vd., 2006; Şanal, 2013). Sonuç olarak, her üç hastanede de örgütsel ustalık durumu mevcut, ancak özel hastane, daha yüksek düzeyde ustadır.

\section{4. İlişki Analizleri}

Hastanelerin sağlık otelciliği hizmetleri ile örgütsel ustalık stratejileri arasındaki ilişkileri test etmek amacıyla iki farklı hipotez oluşturulmuştur. Bunlardan ilki; "Hastanelerde sağlık otelciliği hizmetleri ile yararlanıcı strateji arasında pozitif bir ilişki vardır (H1)" hipotezidir. Sağlık otelciliği hizmetleri ile yararlanıcı strateji arasındaki ilişkinin devlet hastanesinde $(r=, 664)$ pozitif ve güçlü; üniversite hastanesinde $(r=, 349)$ ve özel hastanede $(r=, 417)$ pozitif ve orta düzeyde bir ilişki tespit edilmiştir (Tablo 7). Buna bağlı olarak; $H 1$ kabul edilmiştir.

Tablo 7: Sağlık Otelciliği Hizmetleri ile Yararlanıcı Strateji İlişkisi

\begin{tabular}{|c|c|c|c|c|}
\hline \multirow[b]{2}{*}{ Sağlık Otelciliği Hizmetleri } & \multirow{2}{*}{ 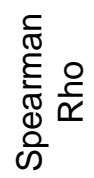 } & \multicolumn{3}{|c|}{ Yararlanıcı Strateji } \\
\hline & & Devlet & Üniversite & Özel \\
\hline & $r$ & ,664 & ,349 & ,417 \\
\hline
\end{tabular}

Tüm korelasyonlar $p<0,001$ düzeyinde anlamlıdır.

Bu çalışmada, sağlık otelciliği hizmetleri ile yararlanıcı strateji arasında pozitif bir ilişki olduğu saptanmıştır. Bu bulgular, önceki çalışmalarla (Akbolat, 2009; Bodwell, 2011) benzer niteliktedir. Ancak devlet hastanesinde sağlık otelciliği hizmetleri ile yararlanıcı strateji birbiriyle güçlü olarak bağlantılı iken, diğer iki hastanede bu durum orta düzeyde bulunmuştur. Bu durum sağlık otelciliği uygulamalarının devlet hastanesinde zorunlu olarak yürütülmesinden kaynaklanabilir.

Çalışmanın ikinci hipotezi "Hastanelerde sağlık otelciliği hizmetleri ile araştırıcı strateji arasında pozitif bir ilişki vardır (H2)" hipotezidir. Bu hipotezin test edilmesi sonucunda sağlık otelciliği hizmetleri ile araştırıcı strateji arasında devlet hastanesinde 
$(r=, 712)$ pozitif ve güçlü, üniversite hastanesinde $(r=, 435)$ ve özel hastanede $(r=, 511)$ pozitif ve orta düzeyde ilişki olduğu görülmektedir (Tablo 8). Dolayısıyla, H2 kabul edilmiştir.

Tablo 8: Sağlık Otelciliği Hizmetleri ile Araştırıcı Strateji İlişkisi

\section{Sağlık Otelciliği Hizmetleri}

\begin{tabular}{|c|c|c|c|}
\hline \multirow{2}{*}{ 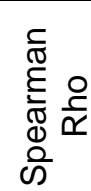 } & \multicolumn{3}{|c|}{ Araştırıcı Strateji } \\
\hline & Devlet & Üniversite & Özel \\
\hline$r$ & ,712 & ,435 &, 511 \\
\hline
\end{tabular}

Tüm korelasyonlar $p<0,001$ düzeyinde anlamlıdır.

Sağlık otelciliği hizmetleri ile araştırıcı strateji arasında ortaya çıkan pozitif ilişki önceki çalışmaları (Bodwell, 2011; Akbolat ve Işık, 2012; Doğan ve diğ. 2017) destekler niteliktedir. Her üç hastanede sağlık otelciliği hizmetleri ile araştırıcı strateji arasında tespit edilen bu pozitif ilişki; devlet hastanesinde güçlü, üniversite ve özel hastanede orta düzeyde gerçekleşmiştir. Devlet hastanesinde görülen bu güçlü ilişki, sağlık otelciliği hizmetlerinin sunulması yanında geliştirilmesi, araştırılması ve yenilenmesi konularında yüksek bir istekliliğin olduğunu göstermektedir. Buna göre devlet hastanesi sağlık otelciliğinin daha ileriye taşınması, gelecekteki ihtiyaçlara göre yeniden tasarlanması için gerekli olan araştırıcı strateji kullanımında da (yararlanıcı stratejide olduğu gibi) güçlüdür. Devlet hastanesinde her iki stratejide ortaya çıkan güçlü ilişki, sağlık otelciliğinin başarısında örgütsel ustalık düzeyinin yakalanmış olduğuna işaret etmektedir. Üniversite ve özel hastanede ise bu ilişkinin orta düzeyde olması, sağlık otelciliğinde örgütsel ustalık stratejilerini birlikte kullanma eğiliminde orta düzeyde olmayı ifade etmektedir. Bu hastanelerde, sağlık otelciliği hizmetlerinin geliştirilmesi için örgütsel ustalık düzeyinin orta düzeyin üstüne çıkartılması gerekmektedir.

\section{Sonuç ve Öneriler}

Hastaneler, günümüzde hızlı değişimlerin yaşandığı dinamik bir çevrede hizmet vermektedir. Bu dinamik yapıya bağlı olarak medikal turizm alanında da daha kaliteli hizmet sunumu ve bunu sağlayacak stratejilerin belirlenmesi önemli hale gelmiştir. Bu bağlamda, otelcilik hizmetlerinin daha önce belirlenmiş olan kategorilerden farklı daha üstün hizmetler verecek şekilde güncellenmesi gerekmektedir. Ayrıca, bu hızlı değişim ortamına dayanak olacak yeni örgütsel yaklaşımların da uygulanması yararlı olacaktır. $\mathrm{Bu}$ amaçla çalışmada, hastanelerdeki otelcilik hizmetlerinin daha başarılı yürütülmesi için bir alternatif yaklaşım olarak örgütsel ustalık önerilmektedir.

Sağlık otelciliği hizmetlerinin yeterli olma durumu itibariyle, ilk sırada özel hastane, ikinci sırada üniversite hastanesi, üçüncü sırada ise devlet hastanesi yer almaktadır. Devlet hastanesinin 95 yıllık, üniversite hastanesinin 51 yıllık hizmet süresine rağmen, özel hastanenin (8 yıllık hizmet süresi) ilk sırada yer alması kamu hastanelerinde bu hizmetlerin özel hastanedeki kadar istenilen durumda olmadığını göstermektedir. Bu gecikme, hastanelerde otelcilik hizmetlerinin önemsenmesine ve bu hizmetlerin tedavi hizmetlerini tamamlayan önemli destekleyici bir alan olduğunun kamuda geç algılanmasına bağlanabilir. Türkiye'de kamu hastanelerinde sağlık otelciliği uygulamalarının başlangıç tarihi 2012 yılıdır (Türkiye Kamu Hastaneleri Kurumu, 2014). Özel hastanelerde ise medikal turizm çalışmalarına 2006 yılında Kültür ve Turizm Bakanlığının planlı sağlık turizmi tanıtımı ve faaliyetleri kapsamındaki 
düzenleme ile başlandığı görülmektedir (Kültür ve Turizm Bakanlığı, 2019). Türkiye'de özel hastanelerin \%94'ü Uluslararası Birleşik Komisyon (JCl) belgesi alarak, sağlık hizmetlerinde akredite oldukları ve Dünyada Tayland'dan sonra ikinci sırada yer aldıkları dikkat çekmektedir (Akbolat ve Deniz, 2017: 127). Medikal turizm sektöründe verilen hizmetlerin teknik açıdan gelişmişliği ve evrensel düzeyde olması önemli olduğundan, hastanelerde bu belgelerin bulunması önemli bir güvenli hizmet göstergesidir.

Hastanelerin sağlık otelciliği hizmetlerinin kategoriler itibariyle durumları ise şöyledir: Sağlık otelciliği hizmetlerinin tamamını devlet hastanesinde kısmen yeterli düzeyde sunulduğu ortaya çıkmıştır. Üniversite hastanesinde; din, atık ve çamaşırhane/terzilik hizmetlerinin yeterli düzeyde iken; danışma, güvenlik, yemekhane/kantin-kafeterya, temizlik, bahçe-otopark ve personel hizmetleri ise kısmen yeterli düzeyde bulunmuştur. Özel hastanede; güvenlik, çamaşırhane/terzilik, atık ve din hizmetlerinin tamamen yeterli düzeyde; danışma, yemekhane/kantin-kafeterya, temizlik, bahçe-otopark ve personel hizmetlerinin ise yeterli düzeyde sunulduğu görülmektedir. Özel hastanelerde otelcilik hizmetlerinin sunumu ile ilgili ortaya çıkan durum, daha önceki çalışmaların (Camilleri ve O'Callaghan, 1998: 131; Sevin, 1998; Kılıç, 2002) sonuçlarıyla da tutarlıdır. Ayrıca, tüm sağlık otelciliği hizmetlerinin sunumunda ilk sırada din hizmetlerinin yer alması ve tamamen yeterli düzeyde bulunması dikkat çekicidir. Bu sonuç, Güden ve diğerlerinin (2010) çalışmasıyla da benzerlik göstermektedir. Din hizmetlerinin öncelikli görülmesi, morg işlemlerinin önemli bir kısmının dini ritüelleri gerektirmesine bağlanabilir. Sağlık otelciliği hizmetleri ile ilgili bir diğer dikkat çekici sonuç ise temizlik hizmetlerinin termal tesislerdekinden daha az önemli olarak algılanmasıdır. Bu çalışmada dördüncü sırada yeterli düzeyde algılanan temizlik hizmetlerinin Bertan ve diğ.'nin (2015) termal tesisler kapsamında yaptıkları çalışmada, ilk sırada yer almaktadır.

Sağlık otelciliği hizmetlerinin sunumunda son sırada ise bahçe/otopark hizmetlerinin bulunduğu ve kısmen yeterli düzeyde olduğu belirlenmiştir. Bahçe ve otopark hizmetleri ile ilgili bu sonuç, önceki çalışmalarla (Selim, 2011; Sakıcı ve diğ., 2013) benzer niteliktedir. Bahçe ve otopark hizmetlerindeki orta düzeyde yeterli olma durumu, Ankara'daki hastanelerin şehir merkezî konumlu olmaları ve yeterli geniş açık alana sahip olmamalarına bağlanabilir.

Araştırmada, hastanelerdeki örgütsel ustalık stratejilerinin kullanımı ile ilgili elde edilen sonuçlar şu şekildedir: Devlet hastanesinde ve üniversite hastanesinde yararlanıcı strateji ve araştırıcı stratejinin birlikte kullanılma eğilimi orta düzeyde; özel hastanede ise her iki stratejinin birlikte kullanılma durumu yüksek düzeydedir. Buna göre, özel hastanenin örgütsel ustalık düzeyi diğer iki hastaneye göre daha yüksektir. Devlet hastanesi ve üniversite hastanesinde her iki stratejinin birlikte orta düzeydeki kullanımı da önemlidir. Bu hastanelerde orta düzeyde de olsa bir örgütsel ustalık durumu söz konusudur. Ancak ustalık durumunda özel hastanelerde sağlanan yüksek düzeyde yeterli olma durumu henüz sağlanamamıştır. Özel hastanenin örgütsel ustalık durumu, sağlık otelciliği hizmetlerindeki yeterli olma durumuna dayanak teşkil etmesi bakımından önemlidir. Diğer iki hastanede ise örgütsel ustalığın daha yüksek düzeye çekilmesi için mevcut ve gelecekle ilgili stratejileri birlikte kullanma alışkanlığının yerleştirilmesi gerekmektedir. Kamusal alanındaki değişimlere hızlı ayak uydurmadaki zorluklar ve günü kurtarma politikalarının egemen olması araştırıcı stratejinin devlet hastanesindeki kullanımı önünde önemli bir engel olarak görülebilir. Her üç hastanede sağlık otelciliği hizmetleri ile yararlanıcı ve araştırıcı stratejiler arasında belirlenen pozitif ilişkili olma durumu ise daha önceki sonuçlarla (Akbolat, 2009; Akbolat ve Işık, 2012; Bodwell, 2011; Doğan ve diğ., 2017) tutarlılık göstermektedir. 
Hastane hizmetlerinin değerlendirilmesinde genellikle hasta görüşlerine yer verildiği görülmektedir. Bu çalışmada ise sağlık otelciliği, örgütsel ustalık açısından ele alındığından, çalışan ve yöneticilerin konu ile ilgili görüşleri daha önemli hale gelmiştir. Araştırmada elde edilen sonuçlardan yola çıkılarak gelecekteki araştırmalarda daha kapsamlı bir coğrafyada, hasta ve refakatçi görüşlerine de yer verilen araştırmaların gerçekleştirilmesi sağlanabilir. Ayrıca, örgütsel ustalık konusu otel işletmeleri, havayolu işletmeleri vb. farklı alanlarında da araştırılabilir. Çalışma kapsamında uygulayıcılara şu öneriler getirilmektedir:

- Sağlık otelciliği hizmetlerinin sağlık ile ilgili tüm konaklama tesislerinde yürütülmesi,

- Sağlık otelciliği hizmetlerinin hastaneler yanında, termal oteller, dezavantajı oteller, 50 Plus oteller gibi diğer ilgili konaklama tesislerinde de yasal güvence altına alınması,

- Sağlık otelciliği hizmetlerinin güncelleştirilmesi için hastane yönetimlerinin politikalar geliştirmesi,

- Yöneticilerin sağılk otelciliği hizmetlerinde ortaya çıkan kısmen yeterli hizmet standartlarını yeterli düzeye çıkarabilmek için personel eğitimine, sağlık otelciliği denetimlerine önem vermelerinin sağlanması,

- Hastanelerde kullanılan kalite belgelerinde yer alan standartların korunması ve sürdürülmesinde gerekli özenin gösterilmesine dikkat edilmesi.

\section{Kaynakça}

Acar, D.G. (2014), Hizmet Tasarımı, Eskişehir: Anadolu Üniversitesi Açıköğretim Yayınları.

Akbolat, M. (2009), 'Türk Sağlık Sektöründe Miles ve Snow'un Stratejik Tipolojisi: Hastaneler Üzerine Bir Araştırma', Gazi Üniversitesi Iktisadi ve İdari Bilimler Fakültesi Dergisi, 11(3), ss. 127-146.

Akbolat, M. ve Deniz, N.G. (2017), 'Türkiye'de Medikal Turizmin Gelişimi ve Bazı Ülkelerle Karşılaştırılması', Uluslararası Global Turizm Araştırmaları Dergisi, 1(2), ss. 123-139.

Akbolat, M. ve Işık, O. (2012), 'Hastanelerde Rekabet Stratejileri ve Performans', Atatürk Üniversitesi Sosyal Bilimler Enstitüsü Dergisi, 16(1), ss. 401-424.

Aksu, A., Gülmez, M. ve Güzel, Ö. (2016). TOBB ve TÜROFED Turizm Sektör Meclisi Turizm Raporu, 6(11), ss. 1-80.

Aktaş, A. (1985), Hastanelerde Yiyecek İçecek Hizmetleri Yönetimi ve Türkiye'de Uygulamaya İlişkin Örnekler. Yayınlanmamış Doktora Tezi. Uludağ Üniversitesi, Sosyal Bilimler Enstitüsü, Bursa.

Aktaş, A. (2007), Hastane İşletmelerinde Ev İdaresi Hizmetlerinden Sağlık Calışanlarının Memnuniyeti Üzerine Bir Araştırma (KTÜ Farabi Hastanesi Örneği). Yayınlanmamış Yüksek Lisans Tezi. Karadeniz Teknik Üniversitesi, Sosyal Bilimler Enstitüsü, Trabzon.

Ankara III Sağlık Müdürlüğü. (2016). Sağlık Tesisleri. https://ankaraism.saglik.gov.tr/, (15.05.2016).

Aşıkoğlu, Ş. (2014), Hastanelerde Otelcilik Hizmetleri. Yayınlanmamış Yüksek Lisans Tezi. Beykent Üniversitesi, Sosyal Bilimler Enstitüsü, İstanbul.

Attar, M. (2014), Üst Düzey Yöneticilerin Liderlik Özelliklerinin Örgütsel Ustalık Düzeyine Etkisi: Türk Bankacılık Sektörü, Ankara: Gazi Kitabevi.

Bertan, S., Bayram, M. ve Benzergil, N. (2015), 'The evaluation of thermal hotels' online reviews'. Turizam, 63 (1), ss. 53-65. 
Bierly, P.E. ve Daly, P.S. (2007), 'Alternative Knowledge Strategies, Competitive Environment and Organizational Performance in Small Manufacturing Firms', Entrepreneurship Theory and Practice, 31(4), ss. 493-516.

Birkinshaw, J. ve Gibson, C.B. (2004), 'Building Ambidexterity into an Organization', MIT Sloan Management Review, Summer (2004), ss. 47-55.

Bodwell, W. (2011), A Theoretical Model of Organizational Ambidexterity in Hospitals, Yayınlanmamış Doktora Tezi, Colorado State University, School of Education, Colorado.

Burgess, N., Strauss, K., Currie, G. ve Wood, G. (2015), 'Organizational ambidexterity and the hybrid middle manager: The case of patient safety in UK hospitals', Human Resource Management, 54(S1), ss. 87-109.

Camilleri, D. ve O'Callaghan, M. (1998), 'A Comparison of Public and Private Hospital Care Service Quality in Malta', International Journal of Health Care Quality Assurance, 11(4), ss. 127-133.

Carmeli, A. ve Halevi, M.Y. (2009), 'How Top Management Team Behavioral Integration and Behavioral Complexity Enable Organizational Ambidexterity: The Moderating Role of Contextual Ambidexterity'. The Leadership Quarterly, 20(2009), ss. 207-218.

Cingöz, A. ve Akdoğan, A.A. (2014), 'Örgütsel Ustalık Düzeyini Belirlemede Araştırıcı ve Yararlanıcı Stratejilerin Etkileşimsel Rolü', Aksaray Üniversitesi Iktisadi ve Idari Bilimler Fakültesi Dergisi, 7(2), ss. 59-68.

Demir, N. (2015), Hastane Bahçelerinin Peyzaj Mimarlığı Açısından İncelenmesi: Ankara Altındağ İlçesi Örneği, Yayınlanmamış Yüksek Lisans Tezi, Ankara Üniversitesi, Fen Bilimleri Enstitüsü, Ankara.

Doğan, İ.F., Bakan, İ. ve Hayva, S. (2017), 'Sağlık Sektörünün Temel Aktörleri Olan Hastanelerde Rekabet Stratejilerinin Kaliteye Etkisi', Elektronik Sosyal Bilimler Dergisi, 16(62), ss. 817-835.

Duncan, R.B. (1976), 'The Ambidextrous Organization: Designing Dual Structures For Innovation', The Management of Organization, 1, ss. 167-188.

Gastaldi, L., Appio, F. P., Corso, M. ve Pistorio, A. (2018), 'Managing the explorationexploitation paradox in healthcare: Three complementary paths to leverage on the digital transformation', Business Process Management Journal, 24(5), ss. 1200-1234.

Gibson, C. B. ve Birkinshaw, J. (2004), 'The Antecedents, Consequences, and Mediating Role of Organizational Ambidexterity', Academy of Management Journal, 47, ss. 209-226.

Gupta, A.K., Smith, K.G. ve Shalley, C.E. (2006), 'The Interplay Between Exploration And Exploitation', Academy of Management Journal, 49(4), ss. 693-706.

Güden, E., Öksüzkaya, A. ve Çetinkara, K. (2010), 'Kayseri İli Kamu Hastanelerinde Sağlıkta Kalite Standartlarının Değerlendirmesi', Sağlıkta Performans ve Kalite Dergisi, 2 (2), ss. 144-166.

Güllüpunar, M.D. (2016), 'Bir Halkla İlişkiler Uygulaması Olarak Hastanelerde Hasta Karşılama Hizmetlerinin Kurumsal İtibara Etkisi: Kamu Hastaneleri Üzerine Bir İnceleme', Gümüşhane Üniversitesi İletişim Fakültesi Elektronik Dergisi, 4(2), ss. 895-925.

Greenhut, A.K., Magnezi, R. ve Shlomo, I.B. (2017), 'Better Patient Safety: Implementing Exploration and Exploitation Learning in Daily Medical Practice'. BMJ Open Quality, 6(2), ss. 1-7.

Han, M. ve Celly, N. (2008), 'Strategic Ambidexterity and Performance in International New Ventures', Canadian Journal of Administrative Sciences, 25, ss. 335-349.

Kültür ve Turizm Bakanlığı (2019), http://yigm.kulturturizm.gov.tr/TR11479/turkiye39de-saglik-turizmine-yonelik-yapilan-calismalar-.html, (18.01.2019). 
Jarvenpaa, A. (2014), Organizational Ambidexterity in Airline Companies, Yayınlanmamış Yüksek Lisans Tezi, Faculty of Social Sciences, Norwegian School of Hotel Management, Norwegian.

Kılıç M. (2002), 'Yozgat Devlet Hastanesinde Yatanların Hastane Otelcilik Hizmetlerini Algılayışlarının Değerlendirilmesi', Sağlık Bilimleri Dergisi, 11(2), ss. 15-24.

Korkmazer, F., Yıldız, A. ve Ekingen, E. (2016), 'Sağlık Personeli Hasta Güvenliği Kültürü Algılarının Değerlendirilmesine Yönelik Bir Araştırma', Muş Alparslan Üniversitesi Sosyal Bilimler Dergisi, 4(2), ss. 141-154.

Koster, F. ve Van Bree, G. (2018), 'How Managers Evoke Ambidexterity and Collaboration: A Qualitative Study in a Dutch Hospital', International Journal of Innovation and Technology Management, 15(06), ss. 1-34.

Lawshe, C. H. (1975), 'A Quantitative Approach to Content Validity'. Personnel psychology, 28(4), 563-575.

Lorcu, F. (2015), Örneklerle Veri Analizi SPSS Uygulamalı, Ankara: Detay Yayıncılık.

Malik, A., Boyle, B. ve Mitchell, R. (2017), 'Contextual ambidexterity and innovation in healthcare in India: the role of HRM'. Personnel Review, 46(7), ss. 1358-1380.

March, J. (1991), 'Exploration and Exploitation in Organizational Learning', Organization Science, 2(1), ss. 71-87.

Özcan, K. (2012), Postmodern Örgüt Kuramı, Ankara: Gazi Kitabevi

Rosenthal, E. (2013, 21 Eylül), Is this a hospital or a hotel? The New York Times.

Sakıcı, Ç., Çelik, S. ve Kapucu, Ö. (2013), 'Kastamonu'daki Hastane Bahçelerinin Peyzaj Tasarımlarının Değerlendirilmesi', SDÜ Orman Fakültesi Dergisi, 14(1), ss. 64-73.

Selim, C. (2011), Otopark Alanlarının Planlama ve Tasarım İlkeleri: Ege Üniversitesi Yerleşkesi Örneği, Yayınlanmamış Yüksek Lisans Tezi, Ege Üniversitesi, Fen Bilimleri Enstitüsü, İzmir.

Sevin, H.D. (1998), Hastane İşletmelerinde Otelcilik Hizmetleri, Maliyeti ve Kontrolü: Ankara İli Uygulama Örnekleri, Yayınlanmamış Doktora Tezi, Gazi Üniversitesi, Sosyal Bilimler Enstitüsü, Ankara.

Sheehan-Smith, L. (2006), 'Key Facilitators and Best Practices of Hotel-Style Room Service in Hospitals'. American Dietetic Association, 106(4), ss. 581-586.

Söyler, S. ve Zekioğlu, A.K. (2017), 'Sağlık Hizmetlerinde Dış Kaynak Kullanımı: Bir Alan Araştırması', Sağlık Yönetimi Dergisi, 1(1), ss. 11-20.

Sağlık Bakanlığı. (2013), Kırşehir İli Kamu Hastaneleri Birliği 2013 Yılı Faaliyet Raporu, http://kirsehirkhb.gov.tr/files/sayfalar/faaliyet.pdf. (17.01.2018).

Sağlık Bakanlığı. (2015), Sağlıkta Kalite Standartları Hastane, Ankara: Pozitif Matbaa.

Soylu, Y. ve İleri, H. (2010), 'Hastanelerde Stratejik Yönetim Uygulamaları S.Ü. Meram Tıp Fakültesi Örneği', Selçuk Üniversitesi Sosyal Bilimler Meslek Yüksekokulu Dergisi, 13(2), 79-96.

Şanal, M. (2013), Çift Yetenekliliğin Pazar Oryantasyonu ve Firma Performansı İle İlişkileri, Yayınlanmamış Doktora Tezi, Gebze Yüksek Teknoloji Enstitüsü, Sosyal Bilimler Enstitüsü, Kocaeli.

Şantaş, F., Şantaş, G., Özer, Ö. ve Şahin, D.S. (2017), 'Sağlık Çalışanlarının Güvenlik İklimi Algılarının Belirlenmesine İlişkin Bir Kamu Hastanesinde Araştırma', Pamukkale Üniversitesi Sosyal Bilimler Enstitüsü Dergisi, 30, ss. 297-307.

Şimşek, Z. (2009), 'Organizational Ambidexterity: Towards A Multilevel Understanding', Journal of Management Studies, 46(4), ss. 597-624.

Taşlıyan, M. ve Gök, S. (2012), 'Kamu ve Özel Hastanelerde Hasta Memnuniyeti: Kahramanmaraş'ta Bir Alan Çalışması', Kahramanmaraş Sütçü İmam Üniversitesi İktisadi ve Idari Bilimler Fakültesi Dergisi, 2(1), ss. 69-94.

Tekin, H. (1993), Eğitimde Ölçme ve Değerlendirme, Ankara: Yargı Yayınevi. 
Tutar, H., Fettahlıoğlu, Ö.O. ve Sayın, Z.F. (2017), 'Bilgi Yönetiminin Örgütsel Ustalık Üzerinde Etkisi Olur Mu?', Journal of Social and Humanities Sciences Research, 4(3), ss. 152-164.

Türkiye Kamu Hastaneleri Kurumu, (2014), Hizmet Sunum Rehberi. Tıbbi Hizmetler Kurum Başkan Yardımcılığı Sağlık Bakım ve Hasta Hizmetleri Daire Başkanlığı. http://www.tkhk.gov.tr/Dosyalar/82d3f45d0cd847979aa4fc9715bfd7c7.pdf. (18.01.2018).

Yılmaz, E. (2017), The Relationship of Organizational Ambidexterity With Whistleblowing Act and Employees' Intention to Leave, Yayınlanmamış Doktora Tezi, Yeditepe Üniversitesi, Sosyal Bilimler Enstitüsü, İstanbul.

Zaim, H. ve Tarım, M. (2010), 'Hasta Memnuniyeti: Kamu Hastaneleri Üzerine Bir Alan Araştırması', Sosyal Siyaset Konferansları, 59, ss. 1-24. 